\title{
Commensals of underground mammals: European mole (Talpa europaea, Eulipotyphla, Talpidae) and the greater mole-rat (Spalax microphthalmus, Rodentia, Spalacidae)
}

\author{
IRINA STEPANOVA, ALEXEY ANDREYCHEV ${ }^{\boldsymbol{*}}$, RUSLAN KULAKHMETOV, EVGENY LOBACHEV \\ Department of Zoology, National Research Mordovia State University. Bolshevistskaya street, 68, Saransk 430005, Russia. Tel./Fax. +7-342-322637, \\ vemail: teriomordovia@bk.ru
}

Manuscript received: 5 September 2021. Revision accepted: 29 September 2021

\begin{abstract}
Stepanova I, Andreychev A, Kulakhmetov R, Lobachev E. 2021. Commensals of underground mammals: European mole (Talpa europaea, Eulipotyphla, Talpidae) and the greater mole-rat (Spalax microphthalmus, Rodentia, Spalacidae). Biodiversitas 22: 4665-4670. The study of lodgers of burrows of underground mammals was carried out using the method of hunting cylinders (cans). In the study, 29 different representatives from the following classes were identified in the courses of the greater mole-rat and European mole: Diplopoda, Chilopoda, Gastropoda, Insecta, Amphibia, and Mammalia. Among the vertebrates captured are Eurasian common shrew (Sorex araneus), Eurasian pygmy shrew (Sorex minutus), bank vole (Clethrionomys glareolus), common spadefoot toad (Pelobates fuscus), moor frog (Rana arvalis), and common toad (Bufo bufo). Twenty-six different species have been identified among invertebrates. Many animals seek shelter in the burrows of underground mammals from enemies and adverse climatic factors for food or conditions for reproduction. In the central part of Russia, more species of commensals were found in European mole burrows (29) than in greater mole-rat burrows (21).
\end{abstract}

Keywords: Burrow, insectivorous mammal, rodent, Russia, small mammals.

\section{INTRODUCTION}

The digging activity of underground diggers as a medium-forming factor is the object of study for many researchers - ecologists, zoologists, soil scientists. Mammalian burrowing activity is one of the most widespread and large-scale phenomena in biogeocenoses. The role of the burrowing activity of vertebrates in the formation of the physical and chemical regime of soils is proved. First of all, the burrowing activity of mammals affects the hardness of the soil, its aeration, thermal regime, water permeability, and humidity. Changing the physical parameters of the soil causes a change in its chemical properties. Under the influence of digging activity from deeper soil horizons, chemical compounds are brought to the surface, more intensively involved in the biogenic cycle. As a result of the burrowing activity of animals, the upper humus horizon is mixed with the underlying parent rock, which contributes to the enrichment of soils with organic matter (Bulakhov 1975). Thus, the activity of diggers is essential not only for the physical and chemical regime of the soil sphere but also for the soil biota.

According to the obligate symbiosis and symbiogenesis principle, the life activity and evolution of all multicellular and the vast majority of unicellular living beings occur only based on integration with other living beings. This integration is carried out by symbiosis, i.e., interspecific relations (synoikia, commensalism, mutualism, parasitism, and others) between the host and its cohabitants (Savinov 2011). However, the study of commensals was carried out in a few animals (Hackman 1963; Platt et al. 2004; Pike and Grosse 2006; Read et al. 2008; Pike and Mitchell 2013; Thornett et al. 2016; Hofstede and Dziminski 2017; Brunke and Buffam 2018; Dawson et al. 2019), due to the incredible complexity of their detection.

Many animals fall into the European mole burrows randomly, some looking for food here, other shelters from adverse climatic influences, and others seeking conditions for reproduction. Based on this principle, the paper considers the hypothesis of the role of burrowing activities of underground diggers in the integration with other animals - commensals of their burrows. While conducting research and developing a methodology for studying the activity of underground mammals (Andreychev 2018, 2019), when recording the noises of the greater mole-rat (Spalax microphthalmus Güldenstaedt, 1770) and the European mole (Talpa europaea Linnaeus, 1758) (Andreychev 2021), we were faced with the problem of possible attribution of the recorded noises not only to the burrow host species themselves but also to their commensals. Noises were received that are not typical for the European mole and the greater mole-rat. Some animals were using the burrows of the shrews. Similarly, the noise of commensals was recorded in the burrows of the Russian desman (Desmana moschata Linnaeus, 1758) (Andreychev et al. 2020). It is known that scientists have recorded animals of different systematic groups in mole burrows (Nesterkova 2013). In the areas of our work, such studies have not been conducted before. Therefore, the study of commensals of the European mole and the greater mole-rat burrows is relevant. In this regard, we set a goal: to identify 
cohabitants and establish the frequency of their occurrence in the burrows of the European mole and the greater molerat in two regions.

To achieve this goal, it was necessary to solve the following tasks: to use different capture methods for the European mole and the greater mole-rat in burrows, and to determine the species composition and frequency of occurrence of individuals of other species. In this paper, along with the results of our research in this direction, we describe a research method that can be used to study symbionts in the burrows of other species of underground animals. In the future, the results obtained for the commensals of the diggers may be of undoubted significance in a comparative sense, especially if the owners live in the same region.

\section{MATERIALS AND METHODS}

The work was carried out in Bolshebereznikovsky, Ruzaevsky districts, Saransk city district (Republic of Mordovia), and Krasnoarmeysk city (Moscow Region) in 2017-2020 (Figure 1). The Republic of Mordovia and Moscow Region is located in the center of the European part of Russia. Geographical coordinates define points of research: $54.187433 \mathrm{~N}$ and $45.183938 \mathrm{E}$ (Saransk), $54.100461 \mathrm{~N}$, and 45.093160 E (Ruzaevsky district), $54.177476 \mathrm{~N}$ and $46.169159 \mathrm{E}$ (Bolshebereznikovsky district), 56.084731 N and 38.132066 E (Krasnoarmeysk). The distance between the points in the Moscow region and Mordovia is $500 \mathrm{~km}$. The climate of the regions is moderately continental, with pronounced seasons throughout the year (Andreychev and Boyarova 2020; Andreychev and Kiyaykina 2020).

The European mole in these areas represents the theriofauna (Andreychev and Kuznetsov 2020). In Mordovia, the European mole is distributed unevenly since the southern border of the range is not far away, namely, in the Penza region south of the city of Penza. The greater mole-rat is a rare species for the fauna of the Republic of Mordovia and is recorded as a local population on the northern border of the range (Andreychev 2019, 2020).

Below we describe the method of studying commensals in the burrows of the European mole and the greater molerat. The classical selective method of trapping described by Voronov (1957) is taken as a basis and modernized based on the tasks set. First, the search for near-surface burrows was carried out, which varied from 50 to $55 \mathrm{~mm}$ in moles and from 100 to $110 \mathrm{~mm}$ in greater mole-rats. The search for European mole burrows is easier on dirt roads than on other sites. In the greater mole-rats, the search for a feeding path was carried out by the earth's emissions from the burrow. Previously, the burrow was checked for occupancy by the owner himself. To do this, digital portable voice recorders Olympus VN-416 PC, VN-712PC were installed in the passages for several days, on the recordings of which the absence or presence of sure diggers was detected by noise. And then, the direct detection of commensals in the burrows was carried out. This paper will not describe the voice recorders method since the descriptions were already presented in previous articles (Andreychev et al. 2017; Andreychev 2018; Lapshin et al. 2018).

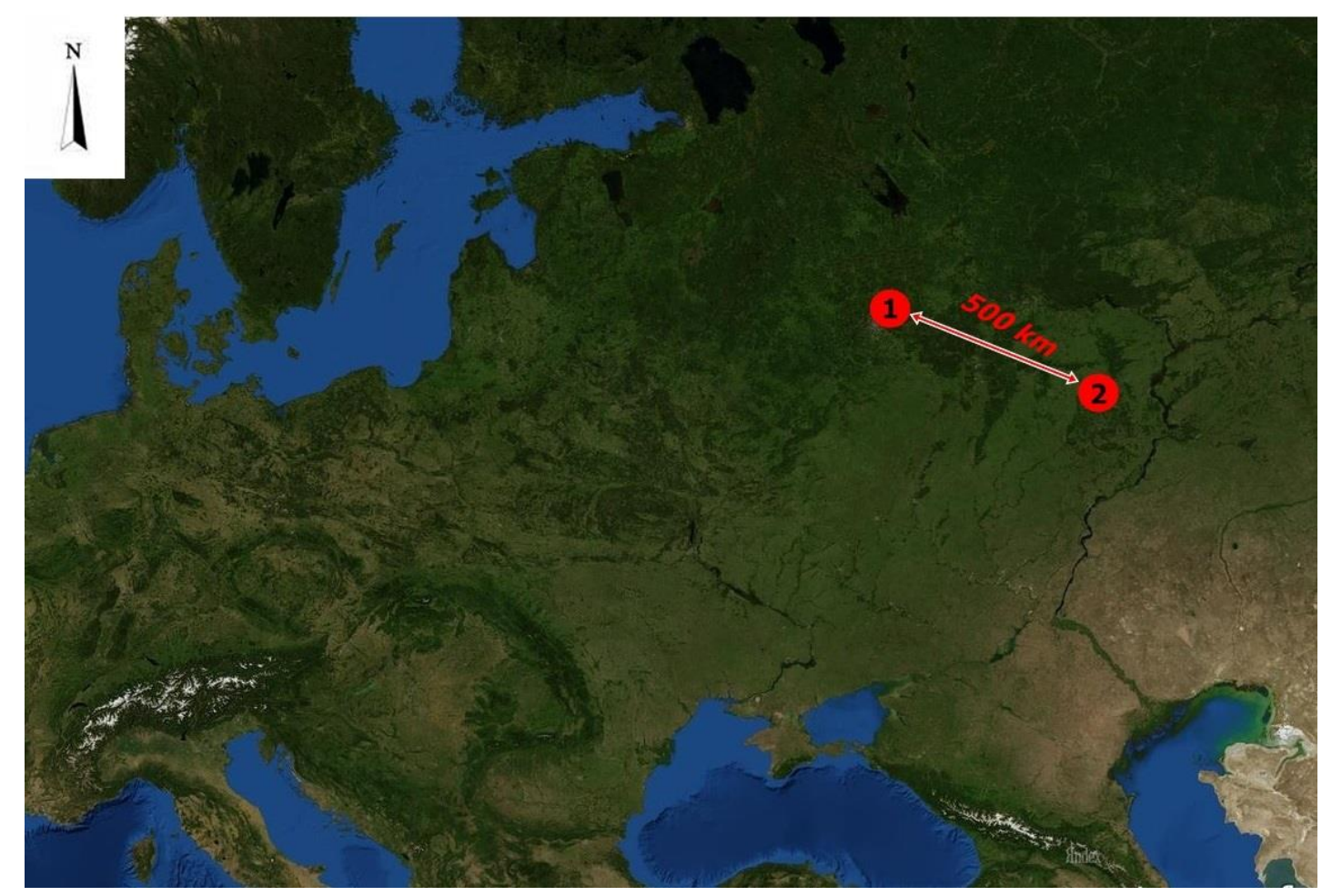

Figure 1. Geographical position of the research areas. Note: red circles with numbers - collection points of the material, $1-$ Moscow region, 2 - Republic of Mordovia, Russian Federation 


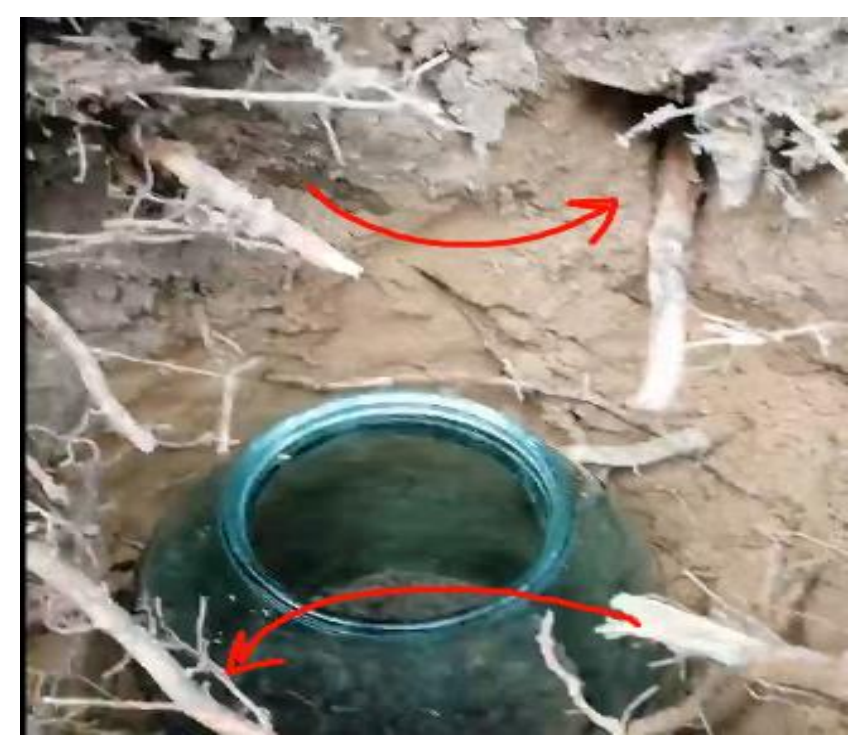

A

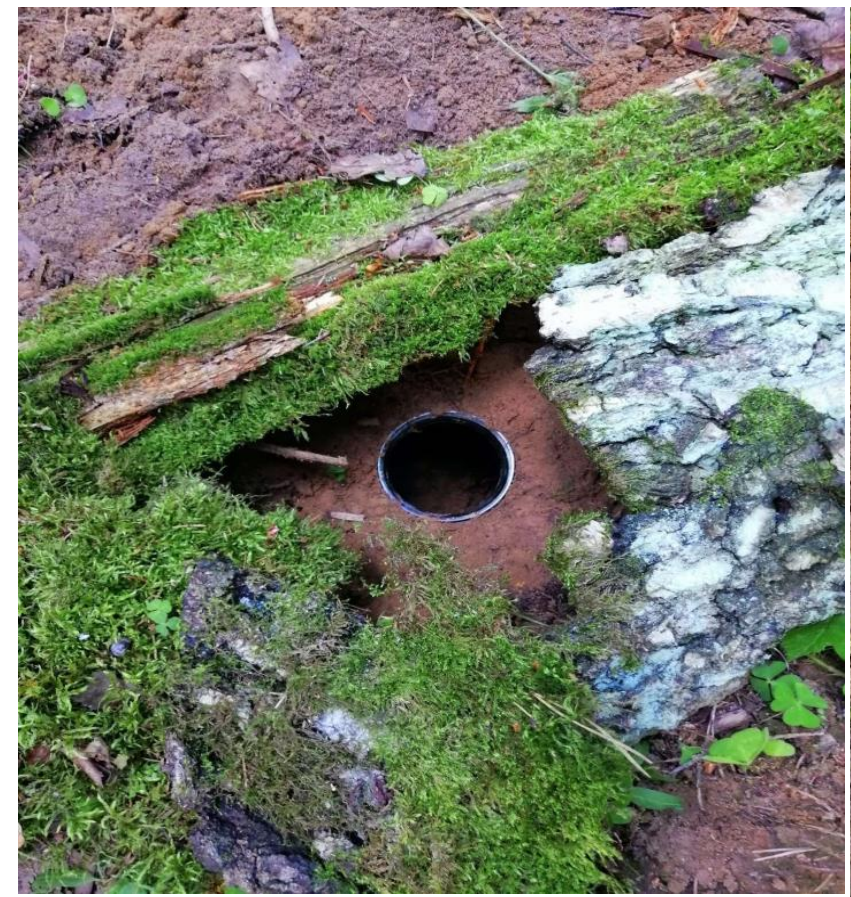

C

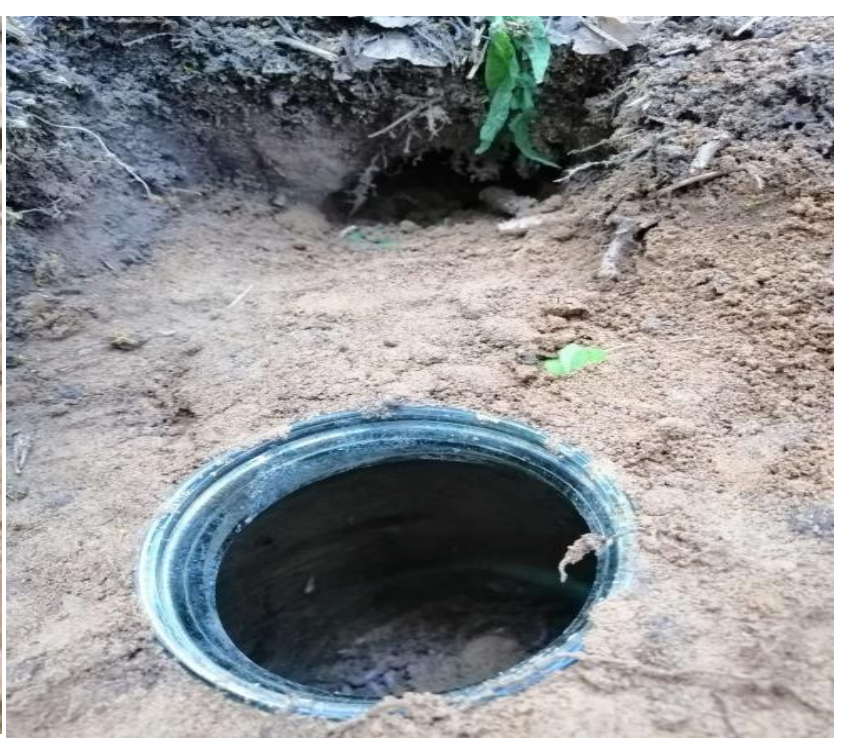

B

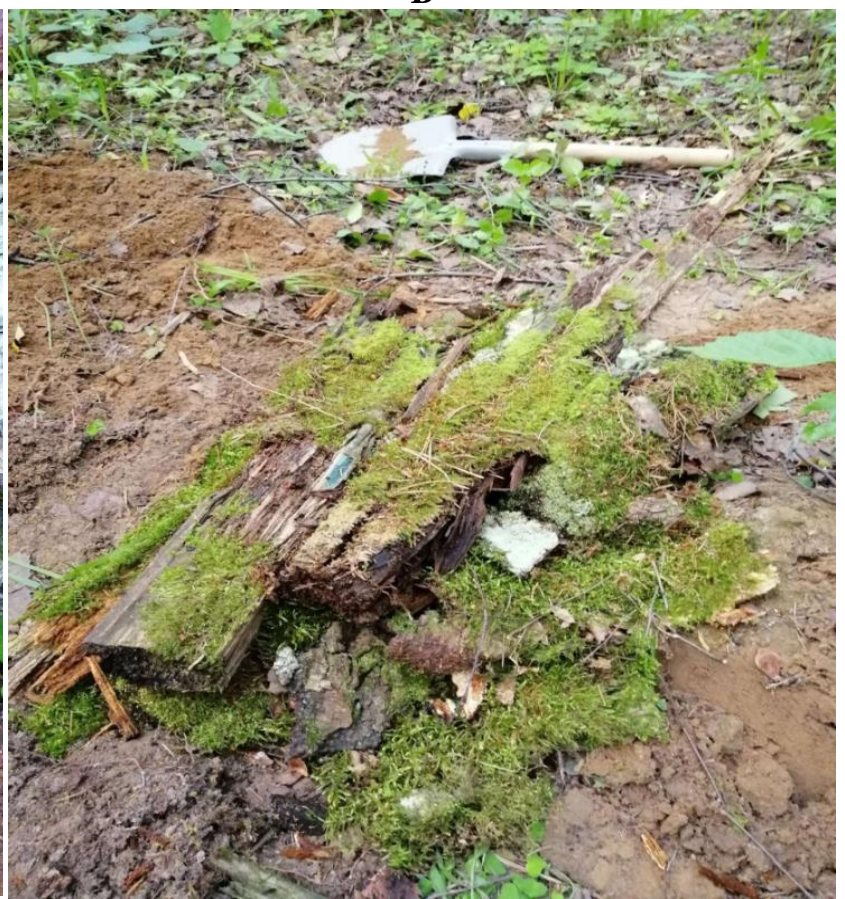

D

Figure 2. Stages of research on the study of European mole commensals. Note: A. Installing the jar in the burrow, the red arrows show the entrances to the burrow; B. Burying the jar with soil around; C. Compacting the soil around the neck of the jar; D. Building a roof over the burrow with a trap

If the noises of a European mole or a greater mole-rat were detected, then the next stage of work was started - the direct catching of commensals in the burrows. To do this, a European mole passage was pulled out along the side of the road, and glass jars (with a volume of 0.5 to 3 liters) were dug into it so that the neck of the jar was dug into the bottom of the passage, i.e., the principle of catching shrews in hunting cylinders was applied. The jar's neck does not allow the European mole to fall into it, while the commensals fall into it. Thus, this technique is reduced to catching the commensals and not the owners of the burrows themselves. In the feeding course of the greater mole-rat, the banks were dug in the immediate vicinity of the earth's outliers. Water was poured into $2 / 3$ of the cans so that the commensals, once in them, could not get out and did not eat each other before the arrival of the researcher. The use of water, rather than other liquids, such as formalin, to fill the cans is because it does not artificially create a situation to attract or repel symbionts in the burrows of shrews. Water has no smell, so the probability of interest to some terrestrial vertebrates or invertebrates of the terrestrial environment is practically excluded. This is an advantage in increasing the objectivity of research work. 
After installing the cans in the bottom of the stern passage, the integrity of the stern passage was restored. For this purpose, an artificial roof made of improvised materials (tree bark, branches, boards, moss, foliage) was used, which covered the upper edge of the passage and was sprinkled with earth on top (Figure 2). This procedure is necessary to prevent ground dwellers from entering the burrows. In addition, to avoid the attention of the owners of the burrows, especially the greater mole-rat. If they find a «draft» in the burrow (open passage), they will bury it, and with it, they will fill up the jar. Moreover, it should be noted that the owners of the burrows themselves can not get into these banks and freely pass through them. Therefore, the traps were checked every other day in the morning. The burrows that got into them were extracted with a net. If necessary, water was added to the jars. Subsequently, the laboratory carried out measurements of the captured inhabitants of the burrows of shrews and the determination of the generally accepted classical determinants. When analyzing the proportion of species recorded in the burrows of shrews, compared with the inhabitants of the ground and underground environments of the two species of secretive mammals, their results and lists of invertebrate species were recorded by other researchers were used.

\section{RESULTS AND DISCUSSION}

In the study, 29 different representatives from the following classes were identified in the courses of the greater mole-rat and the European mole: Diplopoda, Chilopoda, Insecta, Gastropoda, Amphibia, and Mammalia. Among the vertebrates captured are Eurasian common shrew (Sorex araneus Linnaeus, 1758), Eurasian pygmy shrew (Sorex minutus Linnaeus, 1766), Bank vole (Clethrionomys glareolus Schreber, 1780), common spadefoot toad (Pelobates fuscus Laurenti, 1768), moor frog (Rana arvalis Nilsson, 1842) and common toad (Bufo bufo Linnaeus, 1758). It is of interest why these representatives from among the many possible small vertebrates were found in the course of the shrews. In the literature, researchers, in addition to the species we have registered (Voronov 1957; Nakonechny 2013), describe the capture of much other brown-toothed fish, mice, voles, coutars, stoats, weasels, chipmunks, hamsters, and frogs in the European mole passages. Therefore, we consider it appropriate to provide data on the habitat of all possible small vertebrates in these biotopes that we catch (Table 1).

Table 1. Representation of vertebrate species in the biotopes of underground mammals and their burrows. Note: + is animal species marked, - is species of animal not marked.

\begin{tabular}{|c|c|c|c|c|}
\hline Species & $\begin{array}{c}\text { In biotope by } \\
\text { greater mole-rat }\end{array}$ & $\begin{array}{c}\text { In burrow by } \\
\text { greater mole-rat }\end{array}$ & $\begin{array}{c}\text { In biotope } \\
\text { by European mole }\end{array}$ & $\begin{array}{c}\text { In burrow } \\
\text { by European mole } \\
\end{array}$ \\
\hline \multicolumn{5}{|l|}{ Amphibia } \\
\hline Bufo bufo & + & + & + & + \\
\hline Pseudepidalea viridis & - & - & + & - \\
\hline Pelobates fuscus & + & + & + & + \\
\hline Rana arvalis & + & - & + & + \\
\hline Rana temporaria Linnaeus, 1758 & + & - & - & - \\
\hline Lissotriton vulgaris Linnaeus, 1758 & - & - & + & - \\
\hline Triturus cristatus (Laurenti, 1768) & - & - & + & - \\
\hline \multicolumn{5}{|l|}{ Reptilia } \\
\hline Lacerta agilis Linnaeus, 1758 & + & - & + & - \\
\hline Zootoca vivipara (Lichtenstein, 1823) & - & - & + & - \\
\hline Anguis fragilis Linnaeus, 1758 & - & - & + & - \\
\hline Natrix natrix (Linnaeus, 1758) & - & - & + & - \\
\hline Vipera berus (Linnaeus, 1758) & - & - & + & - \\
\hline \multicolumn{5}{|l|}{ Mammalia } \\
\hline Sorex araneus & + & + & + & + \\
\hline Sorex minutus & + & + & + & + \\
\hline Sorex caecutiens Laxmann, 1788 & - & - & + & - \\
\hline Sorex isodon Turov, 1924 & - & - & + & - \\
\hline Neomys fodiens (Pennant, 1771) & + & - & + & - \\
\hline Sicista betulina (Pallas, 1779) & - & - & + & - \\
\hline Clethrionomys glareolus & - & - & + & + \\
\hline Microtus arvalis (Pallas, 1779) & + & - & - & - \\
\hline Micromys minutus (Pallas, 1771) & + & - & - & - \\
\hline Apodemus agrarius (Pallas, 1771) & + & - & + & - \\
\hline Apodemus uralensis (Pallas, 1811) & + & - & + & - \\
\hline Apodemus flavicollis (Melchior, 1834) & - & - & + & - \\
\hline Total number of marked species & 12 & 4 & 21 & 6 \\
\hline
\end{tabular}


We mainly caught the Eurasian common shrew and the Eurasian pygmy shrew in the burrows of the moles. Shrews use the moves of the greater mole-rat and the European mole, as they cannot dig holes independently. In the works of Nakonechny (2013), it was shown that Eurasian common and Eurasian pygmy shrews were more often caught in European mole burrows than on the soil's surface. Other studies have also shown that southern short-tailed shrews (Blarina carolinensis Bachman, 1837) are much more often caught in eastern mole (Scalopus aquaticus Linnaeus, 1758) tunnels than on the ground surface and most often use the passages in the cold season (Hartman et al. 2001). Amphibian catches were isolated, so we consider it appropriate to describe the size of the small representatives. Common toad $\mathrm{L}$ (Longitudo corporis) $=39$, Lc $($ Longitudo capitis $)=11, \quad \operatorname{Ltc}($ Latitudo capitis $)=16$, Dro(Distantia rosstri-oculi $)=3, F($ Longitudo femoris $)=14$, $\mathrm{T}($ Longitudo tibiae $)=9$. Common spadefoot toad $\mathrm{L}=40$, $\mathrm{Lc}=12, \mathrm{Ltc}=17, \mathrm{Dro}=5, \mathrm{~F}=18, \mathrm{~T}=14$. Individuals of the gray toad are yearlings in size. Individuals of the common chesnochnitsa are in terms of size indicators of fingerlings. The small size of the grey toad and the common chesnopsis indicate that they enter the wormholes for shelter and migration. We do not exclude that they may use the burrows of the shrews for food.

Three species from the genera Apporrectodea and Dendrobaena have been recorded from earthworms. Two common species of millipedes have been recorded Rossiulus kessleri (Lohmander, 1927) and Ommatoiulus sabulosus (Linnaeus, 1758). One species, Philonthus politus (Linnaeus, 1758), has been recorded from the family Staphylinidae. Representatives of the genera Aphodius sp., Bolitobius sp. have been recorded from the family Scarabaeidae. Necrophorus vespilloides Herbst, 1784, Necrodes sp., Silpha carinata Herbst, 1783, and Phosphuga atrata (Linnaeus, 1758) have been recorded from the family Silphidae. Dead-eaters are attracted to the European mole passages by the corpses of small mammals and insects. However, in the burrows of the greater molerat, there are practically no corpses of animals. Nevertheless, dead-eaters are the most numerous among insects. Most of the dead-eaters in the moves are represented by the burying beetle $N$. vespilloides. Geotrupidae is represented by one species - the forest dung beetle Anoplotrupes stercorosus (Hartmann in Scriba, 1791). From the family of nutcrackers (Elateridae), Selatosomus cruciatus (Linnaeus, 1758) has been recorded in molehills. From the family of ground beetles (Carabidae), Platysma sp. has been recorded in molehills.

Thus, from the order Coleoptera (Coleoptera). Of the 10 species of beetles captured in the European mole and more excellent mole-rat passages, one species belongs to the family Staphylinidae, respectively, Scarabaeidae -2 and 2, Silphidae -4 and 4, Geotrupidae -1 and 1, Elateridae -1 and 0 , and Carabidae -1 and 0 . Among the saprophages in our collections, the most numerous were representatives of the family Silphidae. Among the necrophages in our collections was a member of the family Staphylinidae. Among the coprophages in our collections was a representative of the family Geotrupidae.
From the order Hemiptera, 1 species was found in the burrows of the European mole - the jumping bug Halticus apterus (Linnaeus, 1758). From the order Hymenoptera, 2 species were found - Vespa crabro (Linnaeus, 1758), Formica rufa Linnaeus, 1761. Ants use significant old outliers of the greater mole-rats soil to build anthills. Thus, many old-earth outliers from burrows at the study site have been turned into anthills. The literature reports that ants (Myrmica and Lasius) quite often populate the soil outliers made by the European mole. Representatives of these taxa are found in Mordovia (Popkova et al. 2021).

From the order Lepidoptera (Lepidoptera), larvae (larvae) were recorded in the passages of the European mole and the greater mole-rat, the species of which was not determined. Perpolita hammonis (Strøm, 1765), was recorded from mollusks in the European mole passages. This type of mollusk should be considered an accidental component of the burrow of the moles. Shellfish records are rare in the burrows of the moles.

Of the 12 species of vertebrates living in the greater mole-rat biotope, 4 species have been identified in its burrows. Of the 21 species of vertebrates living in the European mole biotope, 6 species have been identified in its burrows.

Kharchenko (2014), in his work on the classification of burrowers by ecological groups, refers the greater mole-rat biotope and the European mole to typical geobionts, i.e., species whose life passes underground. A narrow trophic specialization characterizes them. They get their food in underground feeding passages.

Concerning the invertebrates that we have recorded in the greater mole-rat biotope burrows, it is safe to say that they are commensals. The greater mole-rat biotope eats plant food and does not have a trophic relationship with them. The relationship between moles and invertebrates registered in their burrows is more complicated. Moles are insectivorous animals and eat many invertebrates. It is known that the European mole eats earthworms, millipedes, Coleoptera, and Diptera larvae. The mole's diet is usually dominated by earthworms (from 40 to $80 \%$ ), less represented by millipedes, spiders, ground beetles, ants, and they account for up to $30 \%$, larvae of Lamellae $(11 \%)$, larvae of nutcrackers, and blackbirds (7\%), larvae of Diptera, caterpillars, and pupae of butterflies (12\%) (Dzuev et al. 2014). Opinions on the use of centipedes by the European mole vary. Wood (1993) experimentally established that the European mole does not use millipedes, treats them with contempt, and uses mainly earthworms.

Our discovery of ants in the tunnels of the European mole and the greater mole-rat should not be regarded as an accident. This is also evidenced by the results of the work of other researchers (Nakonechny 2013) in Western Siberia, who identified 14 species of ants from 4 genera.

Researchers (Nakonechny and Zinoviev 2016) in Western Siberia recorded 30 different species of beetles from 8 families (Carabidae, Hydrophilidae, Leiodidae, Silphidae, Geotrupidae, Byrrhidae, Nitidulidae, Chrysomelidae). The similarity with our results primarily concerns representatives of the families Silphidae and Geotrupidae. 
Our research results with studies of European mole commensals in the Serebryanoborsky Experimental Forestry and Butovsky Forest Park (Moscow Region) (Bukhareva 2013) show a similar trend. In 2011, 20 species of ground beetles were recorded there, of which 10 were found both on the soil surface and in the European mole passages, and 4 species of weevils, of which only one species of Hylobius abietis (Linnaeus, 1758) was found in burrows.

The results of our research on the European mole's commensals largely explain the work of our predecessors, who were engaged in its nutrition. Many commensals are, in fact, his fodder objects. In the diet of European moles of the Leningrad, Pskov, Novgorod regions, and the Karelian ASSR, representatives of more than 70 taxonomic units, were noted, the basis of food is earthworms (up to $85 \%$ of the total volume) and insects (up to $11.6 \%$ ) (Rusakov 1965). Soil mollusks, millipedes, and other invertebrates were rare. Rodents and lizards in the diet are noted only in the spring.

\section{ACKNOWLEDGMENTS}

We are grateful to S.V. Lukiyanov for help in identifying representatives of invertebrates in burrows of underground mammals.

\section{REFERENCES}

Andreychev AV. 2018. A new methodology for studying the activity of underground mammals. Biol Bull 45: 937-943. DOI: 10.1134/S1062359018080022

Andreychev AV. 2019. Daily and seasonal feeding activity of the greater mole-rat (Spalax microphthalmus, Rodentia, Spalacidae). Biol Bull 46(9): 1172-1181. DOI: 10.1134/S1062359019090012

Andreychev A. 2020. Proportion faunal assemblage of rodents in geoecological districts of Mordovia, Russia. Biodiversitas 21(9): 3961-3968. DOI: 10.13057/biodiv/d210906

Andreychev A. 2021. Activity of the European mole Talpa europaea (Talpidae, Insectivora) in its burrows in the Republic of Mordovia. For Ideas 27(1): 59-67.

Andreychev A, Boyarova E. 2020. Forest dormouse (Dryomys nitedula, Rodentia, Gliridae) - a highly contagious rodent in relation to zoonotic diseases. For Ideas 26(1): 262-269.

Andreychev AV, Kiyaykina OS. 2020. Homing of the forest dormouse (Dryomys nitedula, Rodentia, Gliridae). Zool Zhurnal 99(6): 240-250. DOI: $10.31857 / \mathrm{S} 0044513420060033$

Andreychev AV, Kuznetsov VA. 2020. Checklist of rodents and insectivores of the Mordovia, Russia. ZooKeys 1004(1): 129-139. DOI: $10.3897 /$ zookeys.1004.57359

Andreychev A, Kuznetsov V, Lapshin A, Alpeev M. 2020. Activity of the Russian desman Desmana moschata (Talpidae, Insectivora) in its burrow. Therya 11(2): 161-167. DOI: 10.12933/therya-20-801

Andreychev AV, Lapshin AS, Kuznetsov VA. 2017. Techniques for recording the Eagle owl (Bubo bubo) based on vocal activity. Zool Zhurnal 96(5): 601-605. DOI: 10.7868/S004451341705004X

Brunke AJ, Buffam J. 2018. A Review of Nearctic rove beetles (Staphylinidae) specialized on the burrows and nests of vertebrates. In: Betz O (eds). Biology of Rove Beetles (Staphylinidae): 145-159. DOI: $10.1007 / 978-3-319-70257-5 \& 8$

Bukhareva OA. 2013. Ecological functions of burrowing systems of small mammals in different natural zones of the European territory of Russia. Moscow. [Russian].
Bulakhov VL. 1975. Influence of the burrowing activity of a mole on the physicochemical properties of soils in the forests of the steppe zone of the southeast of Ukraine. Problems of soil zoology. Vilnius, 85-87.

Dawson SJ, Broussard L, Adams PJ, Moseby KE, Waddington KI, Kobryn HT, Bateman PW, Fleming PA. 2019. An outback oasis: the ecological importance of bilby burrows. J Zool 308(3): 149-163. DOI: 10.1111/jzo.12663

Dzuev RI, Sharibova AKh, Dzuev AR. 2014. Features of the population structure and the economic significance of Caucasian mole. Actual problems of ecology and conservation of biodiversity in Russia and neighboring countries: 80-85. [Russian].

Hackman W. 1963. Studies on the dipterous fauna in burrows of voles (Microtus, Clethrionomys) in Finland. Helsinki. [Finland]

Hartman GD, White AM, Wike LD. 2001. Seasonal differences in the use of mole tunnels by short-tailed shrews Blarina carolinensis. Am Midl Nat 145(2): 358-366. DOI: 10.1674/00030031(2001)145[0358:SDITUO]2.0.CO;2

Hofstede L, Dziminski MA. 2017. Greater bilby burrows: Important structures for a range of species in an arid environment. Aust Mammal 39(2): 227-237. DOI: 10.1071/AM16032

Kharchenko NN. 2014. Trophic features of burrowing animals from various ecological groups in the conditions of the Central foreststeppe. For J 3: 107-117. DOI: 10.12737/6275

Lapshin AS, Andreychev AV, Kuznetsov VA. 2018. Daily and seasonal dynamics of the vocalization of the Eagle Owl (Bubo bubo, Strigiformes, Strigidae) in the central Volga region. Zool Zhurnal 97(1): 77-88. DOI: 10.7868/S0044513418010075

Nakonechny NV. 2013. The ecological significance of the moves of common mole (Talpa europaea L., 1758) in the formation of faunistic complexes in the forest zone of Western Siberia. Abstract Dissertation Candidate of Biological Sciences. Moscow. [Russian].

Nakonechny NV. Zinoviev EV. 2016. Comparative analysis of the fauna of beetles (Insecta: Coleoptera) in the tunnels and from the soil surface in the habitats of common mole (Talpa europaea). Actual Problems of Modern Zoology and Animal Ecology. Materials of Russian Scientific Conference, Dedicated to the 70th Anniversary of the Department of Zoology and Ecology of Penza State University and The Memory of Professor V.P. Denisov (1932-1997). Penza State University, Penza. [Russian].

Nesterkova DV. 2013. Faunistic peculiarities of the animal associations in mole's burrows. Povolzhskiy J Ecol 2: 182-189.

Pike DA, Grosse A. 2006. Daily activity of immature gopher tortoises (Gopherus polyphemus) with notes on commensal species. Fla Sci 69(2): 92-98.

Pike DA, Mitchell JC. 2013. Burrow-dwelling ecosystem engineers provide thermal refugia throughout the landscape. Anim Conserv 16(6): 694-703. DOI: 10.1111/acv.12049

Platt SG, Rainwater TR, Brewer SW. 2004. Aspects of the burrowing ecology of nine-banded armadillos in northern Belize. Mammal Biol 69(4): 217-224. DOI: 10.1078/1616-5047-00138

Popkova TV, Zryanin VA, Ruchin AB. 2021. The ant fauna (Hymenoptera: Formicidae) of the Mordovia state nature reserve, Russia. Nat Conserv Res 6(3): 45-57. DOI: 10.24189/ncr.2021.037

Read JL, Carter J, Moseby KM, Greenville A. 2008. Ecological roles of rabbit, bettong and bilby warrens in arid Australia. J Arid Environ 72(11): 2124-2130. DOI: 10.1016/j.jaridenv.2008.06.018

Rusakov OS. 1965. Ecology, trade resources and economic value of a mole (Talpa europaea L.) in northwest areas of the European part of the USSR. Leningrad State University, Leningrad. [Russian].

Savinov AB. 2011. Autocenosis and democenosis as individual - and population-level ecological categories in terms of symbiogenesis and systems approach. Russ J Ecol 42(3): 179-185. DOI: 10.1134/S1067413611030131.

Thornett E, Ostendorf B, Taggart DA. 2016. Interspecies co-use of southern hairy-nosed wombat (Lasiorhinus latifrons) burrows. Aust Mammal 39(2): 205-212. DOI: 10.1071/AM15052.

Voronov NP. 1957. To the study of the fauna of mole passages. Zool Zhurnal 36(10): 1530-1538. [Russian].

Wood DG. 1993. Nests, Burrows and Lairs. In: Strakhova N (eds). Terra, Moscow. 